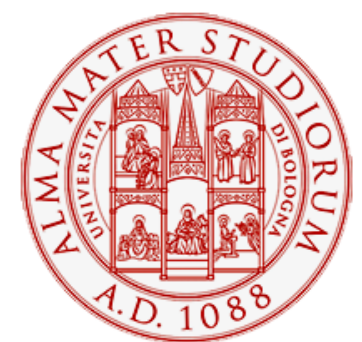

Alma Mater Studiorum - Università di Bologna DEPARTMENT OF ECONOMICS

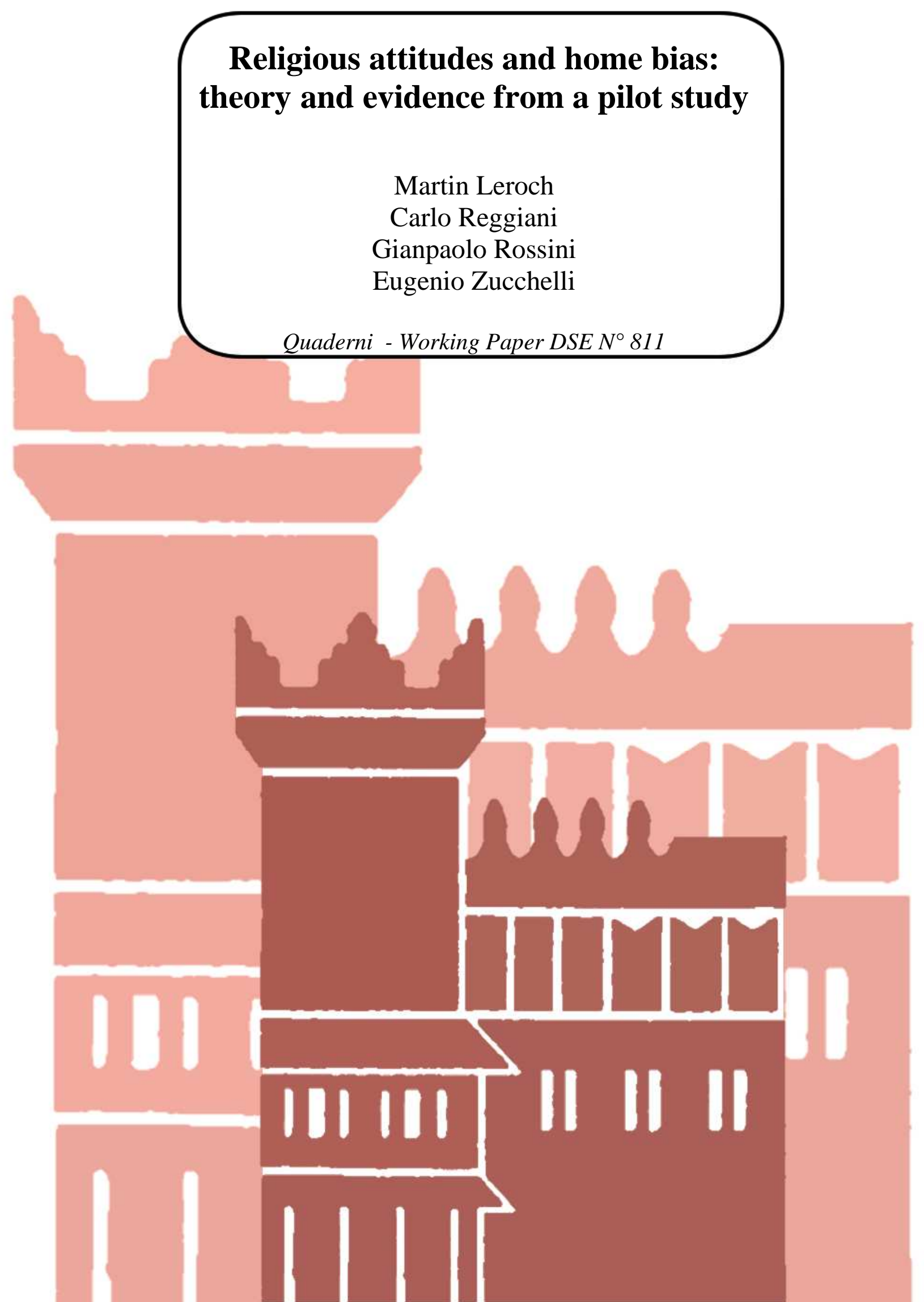




\title{
Religious attitudes and home bias: theory and evidence from a pilot study
}

\author{
Martin Leroch, Carlo Reggianił Gianpaolo Rossini; Eugenio Zucchelli ${ }^{\S}$
}

February 2012

\begin{abstract}
This paper examines the relationship between religion and home bias. We propose a simple theoretical framework that suggests that countries interacting via their representative individuals might show a certain degree of religion-driven international altruism that in turn affects trade. We test these predictions exploiting data from a survey on religious attitudes and individuals' preferences over consumption of home-produced versus foreign goods that we designed and carried out in 15 different countries. We find evidence that religious openness and home bias are negatively correlated. This appears to provide some support to the hypothesis that religious openness, through trust and altruism, may have a pro-trade effect.
\end{abstract}

Keywords: religion, home bias, openness, pilot survey.

JEL classification: Z12, Z10, F15.

${ }^{*}$ Department of Political Sciences, Johannes Guttenberg University, Mainz, Germany. Email: martin.leroch@googlemail.com.

${ }^{\dagger}$ School of Social Sciences - Economics, University of Manchester, Arthur Lewis Building, Manchester M13 9PL, United Kingdom. E-mail: carlo.reggiani@manchester.ac.uk.

${ }^{\ddagger}$ Department of Economics, University of Bologna, Strada Maggiore 45, 40125 Bologna, Italy. E-mail: gianpaolo.rossini@unibo.it.

${ }^{\S}$ Centre for Health Economics, University of York, York YO10 5DD, United Kingdom. Email: eugenio.zucchelli@york.ac.uk. The findings, interpretations and conclusions expressed in this paper are those of the author and do not necessarily reflect the views of the institutions to which he is affiliated to, including the Centre for Health Economics, University of York. 


\section{Introduction}

The home bias effect (HB) is a well-documented phenomenon that arises in international finance and trade (French and Poterba, 1991; Tesar and Werner, 1995; McCallum, 1995) and refers to a preference for goods and services that are home produced. Home bias constitutes an intangible barrier between countries that hampers the effectiveness of governments' efforts to promote trade. Despite its relevance, the causes of home bias are not yet fully understood. Home bias can be partly explained by both physical and bureaucratic barriers between countries such as transportation costs (Obstfeld and Rogoff, 2000), international tariffs and duties (Frankel et. al, 1995; Heliwell, 1998; Lewis, 1999), exchange rate risks (Stulz, 1981; Adler and Dumas, 1983) and asymmetric information (Ahearne et al., 2004; Stulz, 2005). Nonetheless, the literature acknowledges that there is a residual share of home bias that still remains unexplained (Lewis, 1999; Bradford and Lawrence, 2002; Sercu and Vanpee, 2007). Part of the unexplained component of home bias may depend on an individual's embeddedness in a social network. Some authors have suggested that the degree to which individuals are enmeshed in a social network might affect trust and ultimately influence economic choices (Butler et al., 2009; Guiso et al., 2006 and 2009).

Religion is an important part of an individual's life and provides the basis for social aggregation and the development of intangible networks. Religion can affect people through personal involvement, the influence of peers and local religious groups and institutions and also via the impact it may have on political decisions. Historically, sharing the same religious affiliation has helped to promote and enforce cooperative behaviours. For example, during the Middle Ages Maghribi traders successfully managed long-distance trade in the Mediterranean region as the common religion increased mutual trust within merchants belonging to the same religious network (Greif, 1989, 1992, 1993, 1994). Leeson (2005) provides a similar argument about trade in pre-colonial Africa where social proximity, signalled by religion and other social attributes, was the main support for trade. In contemporary societies religion appears to be related to trust and altruism (Schoenfeld, 1978; Bahr and Martin, 1983; Guiso et al., 2006; Hoff, 2010; Henrich et al., 2010) and these have important effects on economic activities and trade (Knack and Keefer, 1997; La Porta et al., 1997; Guiso et al., 2009; Forsythe et al., 1994; Lindbeck and Nyberg, 2006; Laury and Taylor, 2008; Tabellini, 2008).

The aim of this paper is to explore whether embeddedness into a religious network influences individuals' attitudes towards home bias. First, we propose a theoretical framework that outlines the relationship between religion and home bias. In this model, countries interacting via their representative individuals show some degree of religion-driven international altruism that, in turn, affects trade. Second, we present individual-level information on religious attitudes

and home bias drawn from a pilot survey that we have designed and carried out in fifteen countries. To the best of our knowledge this is the first survey 
that attempts to collect comprehensive information on different dimensions of religious attitudes and home bias ${ }^{1}$. Finally, we exploit this information and analyze empirically the influence of religious attitudes on home bias.

In the past the relationship between religion and economic behaviour has captured the attention of prominent scholars such as Adam Smith and Max Weber $^{2}$. More recently the literature on the relationships between religion, economic activities and growth has flourished rapidly (Blum and Dudley, 2001; Ekelund et al., 2002; Barro and McCleary, 2003, 2005; Guiso et al., 2003; Glaeser et al., 2004; Cavalcanti et al., 2007; Becker and Woessmann, 2009). A stream of studies has focused on the nature of religious organizations, the "religious market", its "competitiveness" and how these influence religious participation. According to these studies, in the spirit of Adam Smith's work, religious denominations compete in the market to attract affiliates or maximize alternative objective function s (Iannacone, 1992, 1998; Hungerman, 2011; Finke and Stark, 1988, 1989; Voas et al., 2002; Montgomery, 2003; Gruber and Hungerman, 2008). Previous studies have also analysed the impact of religion on international trade. Lewer and Van den Berg $(2007 a, b)$ employ a gravity model that allows for religion to explain pairwise international trade flows between countries. These studies attempt to disentangle institutional and network effects of sharing a common religion. Helble (2007) also uses a gravity approach but focuses on specific religious denominations and their impact on trade. His findings highlight that religious openness, measured by the variety of religions in a country, is among the most important determinants of bilateral trade. Both Lewer and Van den Berg (2007 a,b) and Helble (2007) aim at identifying the impact of shared religious affiliations on country-level trade flows. Guiso et al. (2009) focus on the influence of culture on trade. The authors employ several proxies of cultural traditions, including sharing a common religion, to explain bilateral trust. They find that culture affects bilateral trust and that this has a large impact on both trade and investment between countries. Finally, Benjamin et al. (2010) attempt to identify the effects of religious affiliations on a series of economic attitudes using individual level data collected through experiments on individuals' contribution to public goods. The use of experiments is mainly due to the lack of both data and sound empirical evidence on the influence of religion on economic choices. According to their results, Protestants appear to be more inclined to pay for public goods, while lower risk aversion may explain the level of contribution of Catholics.

Our paper contributes to the literature in several ways. First, our theoretical framework offers a description of the complex interactions between religion, altruism and home bias through a two-stage game model between countries' rep-

\footnotetext{
${ }^{1}$ This study is part of a larger research project that aims at exploring the relationships between religion, culture and home bias in comparative perspective. The questionnaire presented here is a pilot for a future broader survey.

2 Adam Smith in his seminal book "The Wealth of Nations" (1776) is believed to be the first author to have analyzed religion as a market. Max Weber (1930) famously argued that the Protestant ethic was crucial for the development of own enterprises and the accumulation of wealth in Northern Europe.
} 
resentative individuals. Second, we focus our analysis at the individual rather than aggregate level and examine the influence of individuals' religious attitudes on a series of individual-level choices that define home bias (e.g. labour market decisions and choices about consumption of goods and services and cultural media). Moreover, differently from previous studies, we go beyond the association between religious affiliations and trade by accounting for a wider set of attitudes towards religion such as religious openness, intensity of belief and the importance of religion in an individual's life.

The paper is structured as follows. Section 2 illustrates our theoretical framework while section 3 presents the survey we have designed and the data we have collected. Section 4 illustrates the empirical strategy and its results. Section 5 concludes.

\section{A simple theoretical approach to religion and home bias}

We present a simple theoretical framework that describes the relationship between religion and home bias. The starting point is a simple two-country model based on the analysis of institutional governance provided by Dixit (2009). The model shows how in each country individuals' religious openness may generate more cooperative behaviour and lower cultural barriers towards goods and services produced in a foreign country.

In our model income $(y)$ is generated by the representative individual's production effort $(x)$. The production effort may be enhanced by the extent of the representative individual's degree of openness $(z)$. Openness measures the individual's political favour towards free trade, the competition of foreign consumption patterns and competition from foreign fellow workers. Openness may be considered as beneficial, yet costly, to individual welfare if it is reciprocated. Therefore, partner countries' openness boosts further the per capita income of a community which eventually makes for a larger welfare. In this context, each country representative individual may take into consideration the welfare of partner countries. This corresponds to a form of international altruism. We assume that the extent of reciprocation is related to religious openness. These considerations are embedded in the ensuing formal relationships.

The representative individual in country $i$ derives her income $y_{i}$ according to the following relation:

$$
y_{i}=\left(1+\frac{\sum_{k=1}^{2} z_{k}}{2}\right) x_{i}
$$

with $i=1,2$ countries engaging in reciprocal trade and constituting the world. $z_{i}$ is the openness commitment of each individual in country $i$ and $x_{i}$ is the 
individual effort commitment or the extent of resources individually devoted to production. Then, from the above relationship it appears that the internal commitment to production can be magnified in terms of income according to the degree of openness of the country itself and of partner countries.

The representative agent in each country has a utility function which may look as follows:

$$
u_{i}=y_{i}-\alpha\left(z_{i}+x_{i}\right)^{2}+r_{i} r_{j} u_{j} \quad \forall i, j=1,2 ; \quad j \neq i
$$

where $u_{i}$ is the utility or welfare of the representative individual of country $i$, while $\alpha \in] 0,1]$ is a discomfort sensitivity parameter. The quadratic form in brackets is due to the nonlinearity of the discomfort that is in turn due to both effort and the interaction with the willingness to be open. The third part of (2) is associated to altruism (Lindbeck and Nyberg, 2006; Tabellini, 2008). We introduce cross border altruism in the collective utility function assuming that each country appreciates the welfare of partner countries. In other words we think of countries as not rival but, on the contrary, somewhat altruist ${ }^{3}$. This sort of collective altruism may interact - i.e., may be enhanced or decreased by the extent of religious openness $\left(r_{i, j} \in(0,1)\right)$ in all countries, which is represented by an index of religious openness of one individual multiplied by the same index of the foreign agent. In other words, the utility of a representative individual of country $i$ grows with the utility of individual of country $j$ and the extent of religious openness in both countries. Following this assumption we will be able to introduce a relationship between religion and willingness to be open, the opposite of home bias. The religious openness index may be seen as the extent of cross border altruism of a country towards other communities as a result of the attitude towards religion.

Representative individuals interact as Nash players to maximize their utility using two controls: openness and effort. The timing of the game is as follows. First, countries decide the amount of openness. Second, they set their optimal production effort. The game is solved using standard backward induction with sub-game perfection. In that case, the resulting equilibrium may be described in its properties and comparative statics, in the following:

Proposition 1 (i) Suppose that countries interacting via their representative individuals, show some degree of religion-driven international altruism. Then, there may exist an international equilibrium in efforts and openness with non negative levels of both, non negative per capita income and individual welfare. (ii) Religion affects the extent of altruism and interacts with openness. A higher degree of religious openness increases trade openness at home and abroad. Moreover religious openness leads to a higher income.

Proof. (i) We proceed by getting the reduced forms of each country's repre-

\footnotetext{
${ }^{3}$ This altruism may simply be the awareness of the median voter of a country that openness is good and home bias and/or mercantilism is bad.
} 
sentative individual welfare function:

$$
u_{i}=\frac{2\left[\left(x_{i}+z_{i}\right)^{2}+r_{i} r_{j}\left(x_{j}+z_{j}\right)^{2}\right] \alpha-\left(x_{i}+r_{i} r_{j} x_{j}\right)\left(2+z_{i}+z_{j}\right)}{2\left(r_{i}^{2} r_{j}^{2}-1\right)},
$$

The two countries' representative individuals maximize their respective utility. A Nash equilibrium of the two stage game in both production effort $(x)$ and openness $(z)$ may be found. The equilibrium utility and production for country $i$ and $j$ are:

$$
\begin{gathered}
x_{i}^{*}=\frac{4 \alpha}{6 \alpha+r_{i} r_{j}(2 \alpha-1)-1}=x_{j}^{*}, \\
z_{i}^{*}=\frac{1+r_{i} r_{j}-4 \alpha}{6 \alpha+r_{i} r_{j}(2 \alpha-1)-1}=z_{j}^{*}, \\
u_{i}^{*}=\frac{\left(r_{i} r_{j}+1\right)\left(1+r_{i} r_{j}-8 \alpha\right) \alpha}{\left(r_{j} r_{i}-1\right)\left(1+r_{i} r_{j}-2\left(3+r_{i} r_{j}\right) \alpha\right)^{2}}=u_{j}^{*} \\
y_{i}^{*}=\frac{8\left(1+r_{i} r_{j}\right) \alpha^{2}}{\left[6 \alpha-1+r_{i} r_{j}(2 \alpha-1)\right]^{2}}=y_{j}^{*}
\end{gathered}
$$

The non-negativity of the two endogenous variables $z$ and $x$, for any $r_{i, j} \in[0,1)$, requires that:

$$
\alpha \in\left[\alpha_{1}, \alpha_{2}\right]
$$

where $\alpha_{1}=\frac{r_{i} r_{j}-1}{6+2 r_{i} r_{j}}$ and $\alpha_{2}=\frac{1+r_{i} r_{j}}{4}$. The same holds for $u_{i, j}^{*}$ and $y_{i, j}^{*}$.

(ii) As for the comparative statics results, we may show that

$$
\begin{gathered}
\frac{\partial z_{j}}{\partial r_{i}}=\frac{8 r_{j} \alpha^{2}}{\left[6 \alpha-1+r_{i} r_{j}(2 \alpha-1)\right]^{2}} \geq 0, \\
\frac{\partial z_{j}}{\partial r_{j}}=\frac{8 r_{i} \alpha^{2}}{\left[6 \alpha-1+r_{i} r_{j}(2 \alpha-1)\right]^{2}} \geq 0, \\
\frac{\partial x_{j}}{\partial r_{i}}=\frac{4 r_{j}(1-2 \alpha) \alpha}{\left[6 \alpha-1+r_{i} r_{j}(2 \alpha-1)\right]^{2}} \geq 0 \\
\frac{\partial x_{j}}{\partial r_{j}}=\frac{4 r_{i}(1-2 \alpha) \alpha}{\left[6 \alpha-1+r_{i} r_{j}(2 \alpha-1)\right]^{2}} \geq 0 \\
\frac{\partial u_{i}}{\partial r_{i}}=\frac{r_{j} \alpha\left[\left(1+r_{i} r_{j}\right)^{3}-2\left(1+r_{i} r_{j}\right)^{2}\left(7+r_{i} r_{j}\right) \alpha+32\left(2+r_{i} r_{j}\left(1+r_{i} r_{j}\right)\right) \alpha^{2}\right]}{\left(r_{i} r_{j}-1\right)^{2}\left[6 \alpha+r_{i} r_{j}(2 \alpha-1)-1\right]^{3}} \geq 0 \\
\frac{\partial y_{i}}{\partial r_{i}}=\frac{8 r_{j} \alpha^{2}\left[1+2 \alpha+r_{i} r_{j}(1-2 \alpha)\right]}{\left[-1+6 \alpha+r_{i} r_{j}(2 \alpha-1)\right]^{3}} \geq 0 .
\end{gathered}
$$

Cross effects are:

$$
\frac{\partial u_{i}}{\partial r_{j}}=\frac{r_{i} \alpha\left[\left(1+r_{i} r_{j}\right)^{3}-2\left(1+r_{i} r_{j}\right)^{2}\left(7+r_{i} r_{j}\right) \alpha+32\left(2+r_{i} r_{j}\left(1+r_{i} r_{j}\right)\right) \alpha^{2}\right]}{\left(r_{i} r_{j}-1\right)^{2}\left[6 \alpha+r_{i} r_{j}(2 \alpha-1)-1\right]^{3}} \geq 0
$$




$$
\frac{\partial y_{i}}{\partial r_{j}}=\frac{8 r_{i} \alpha^{2}\left[1+2 \alpha+r_{i} r_{j}(1-2 \alpha)\right]}{\left[-1+6 \alpha+r_{i} r_{j}(2 \alpha-1)\right]^{3}} \geq 0 .
$$

The signs hold in the feasible set, i.e., for $\alpha \in\left[\alpha_{1}, \alpha_{2}\right]$.

\section{Discussion}

Religions may be associated to trade openness if they increase cross-border altruism. This has a beneficial influence on income and feeds back on the productive effort. Religious openness motivates individuals to be more altruistic, reducing the relative cost of discomfort. As for cross effects, religions may support partner country's income and overall welfare. This is a further effect of international altruism induced by religious openness. Then, religious openness should be associated to lower levels of home bias.

\section{Data}

In this section we present individual-level data on religious and economic attitudes obtained through a survey questionnaire that we designed and collected. We subsequently use this data to examine empirically the relationship between religion and home bias. Copies of the questionnaire were distributed to students in 16 universities of 15 countries during the period 2008-2010 . After collecting the data, our final sample consists of 1849 individuals. With the exception of Finland (76), Argentina (86), Ukraine (95) and Japan (99), we received more than 100 completed questionnaires from each country (see Table 1). The largest amount of replies were obtained from Germany (200), followed by India (162) and Italy (148).

The survey focuses on a series of questions that attempt to proxy both religious attitudes and home bias $^{56}$. More specifically, religious attitudes are identified through a set of questions that attempt to define religious openness; the relevance of religion in an individual's life; religious intensity; as well religious affiliation Home bias is captured by questions that aimed at revealing individuals' preferences in three main dimensions: labour market decisions; consumption of home-produced versus foreign goods and services (including health care); and interests in foreign cultures and consumption of foreign media. The

\footnotetext{
${ }^{4}$ The questionnaire was distributed in the following universities and countries: University of Bologna in Buenos Aires, Argentina; Zhejiang University in Hangzhou, China; University of Turku, Finalnd; University of Marseille - Aix en Provence, France; University of Hamburg, Germany; National Law School in Bangalore, India; Univeristy of Bologna in Forlì, Italy; Recanati Graduate School of Business Administration in Tel Aviv, Israel; Ryukoku University, Japan; University Carlos III in Madrid, Spain; University of Lausanne, Switzerland; Bilgi University in Istanbul, Turkey; Kiev School of Economics, Ukraine; University of York, United Kingdom; Brown Univesity and New York University at Binghampton, United States. A.

${ }^{5}$ The English language version of the questionnaire used in the US is available in Appendix

${ }^{6}$ The questionnaire was issued in the language predominantly used during lectures of each university (e.g. English in India, etc.).
} 
survey also contains questions on respondents' demographic characteristics such as age, gender and nationality ${ }^{7}$.

Table 1: Number of respondents by country

\begin{tabular}{llllll} 
Argentina & 86 & & Japan & 99 \\
China & 130 & & Spain & 114 \\
Finland & 76 & & Switzerland & 139 \\
France & 103 & & Turkey & 101 \\
Germany & 200 & & Ukraine & 95 \\
India & 162 & & UK & 138 \\
Italy & 148 & & USA & 144 \\
Israel & 114 & & \\
\hline
\end{tabular}

\section{Descriptive statistics}

\section{Religion and religious attitudes}

Tables 2 displays basic descriptive statistics and clarifies the content of the questions about religion and home bias.

\section{[INSERT TABLE 2 HERE]}

The largest percentage of respondents $(26 \%)$ considers themselves as believers, although they report not attending religious services. Atheists are the second-largest group (21\%) followed by believers attending services (14\%). About a third of the respondents have attended services from religions they do not share and about a quarter of the entire sample of respondents self-report reading holy texts from other religions. Even though $55 \%$ of individuals report being believers, the amount of those who wish to have the state comply with religion on matters such as abortion is relatively low (18\%). $10 \%$ of individuals in the sample would favour the state to support religion (one or the most professed ones) and to have religion affecting politics $(10 \%)$; the same percentage would like a state religion. Also, 39\% would like religious principles to be taught at school.

Only $16 \%$ of our sample of respondents wishes religion to be a guide for the welfare state. The low importance attributed to religion in public choices and moral guidelines is also reflected by the low percentage of those who believe religion has a high importance for their private matters (20\%). Almost half of respondents (44\%) think home-based firms should trade with a country without religious freedom. Only $20 \%$ think that there should definitely be no trade with countries with no religious freedom.

As for religious affiliations, Christians represent the largest religious group (with

\footnotetext{
${ }^{7}$ Questions on individual or household income have not been included due to the important share of missing answers in a related previous survey, reported in Reggiani and Rossini (forthcoming).
} 
$15.7 \%$ of Catholics $10.2 \%$ of Protestants and $10 \%$ on other non-specified Christians). The largest non-Christian groups are formed by Hindus (9.1\%) and Jews (8.2\%). Members of Orthodox churches constitute the smallest groups with 5.8\% of respondents while non-believers amount to up $7.5 \%$ of our respondents.

Overall, replies also indicate that despite the relatively large percentage of believers, about one third of them neither respects nor thinks positively of strong believers. Moreover, less than $20 \%$ consider religion to offer guidance for important personal and institutional issues such as abortion and the welfare state. Nonetheless, a good disposition towards strong believers touches almost half of the sample. This might mean that religion is considered as an important phenomenon to be open to, yet not much to comply with.

\section{Proxies of home bias}

Table 3 reports descriptive statistics and contents of the questions related to home bias.

[INSERT TABLE 3 HERE]

Home bias and labour market choices

We have included two questions about the respondents' willingness to accept a temporary job abroad (up to three years) with the same work conditions as in the home country. $47 \%$ of individuals in our sample would accept such a job offer. This percentage increases to $65 \%$ when we consider a foreign wage a $20 \%$ higher than the home salary ${ }^{8}$.

Home bias and consumption of home versus foreign goods and services

We ask respondents to choose between buying a nationally manufactured and/or branded car or a foreign car with analogous features. According to our interpretation, a preference for the home manufactured car may signal a potential home bias. In our sample, $40 \%$ of respondents would prefer to buy a nationally branded/produced car. We put a similar question related to food consumption. $55 \%$ of individuals in our sample would prefer to buy locally produced over imported food. However, attitudes towards food consumption may relate to other factors such as preferences for fresher locally grown food or environmental concerns. In order to identify preferences over consumption of health care, we ask respondents whether they would prefer to be treated by a local rather than a foreign doctor. The majority of individuals in our sample appears to distrust foreign doctors. This may partly confirm at individual level what has been observed before at macro level suggesting that countries are more open to trade goods than services (Nordas, 2010).

\footnotetext{
${ }^{8} \mathrm{~A} 20 \%$ wage gap with respect to a home-based job may seem a low compensation for leaving the country; however, our sample is composed by young students, well-raised in a time of increasing globalization and cultural exchanges. This could partly explain the high percentage of individuals willing to accept this type of offer.
} 
Home bias, foreign culture, media culture and international socialization

Aggregate "home bias" appears to decrease when considering cultural issues. $25 \%$ of individuals in our sample prefer national writers, $48 \%$ watch news from foreign broadcasters and only $7 \%$ declare no interest in foreign cultures. On the contrary, $76 \%$ of respondents travelled scantily abroad during the last 2 years, while a good portion has foreign friends ( $42 \%$ have between 1 and 5 foreign friends while $43 \%$ has more than 5 ).

\section{Previous surveys on aspects of religion and home bias}

The World Value Survey (2005) is a primary source of data and a reference point for the study of many aspects of culture and well-being, including religion ${ }^{9}$. The last wave of the survey contains two questions that are comparable to ours (Importance of religion in private life; Religion as guidance to welfare state). Another question (Belief in hell) was included in the EconomistYouGovPolymetrix (2008) survey on Anglo-Saxon attitudes. On top of that, our survey covers aspects of the religious sphere (religious openness, affiliation importance in life, intensity of belief) and home bias (home bias in the labour market, in the goods, services markets and in the cultural choices) providing information that could not be otherwise accessed. A comparison of the frequencies registered in the comparable questions is reported in Appendix B; given the nature of our sample, however, no conclusions should be drawn from these.

\section{Empirical analysis}

We analyze data drawn from our survey to provide evidence on the relationship between religious attitudes and home bias. More specifically, in this section we test whether the embeddedness into a religious network (defined through a series of attitudes towards religion as well as religious affiliation) is correlated with home bias. Home bias is identified through individuals' labour market choices and preferences towards consumption of health care, and home-produced versus foreign goods and services. As suggested by our theoretical framework we expect religious openness to be negatively correlated with home bias: a higher degree of religious openness should decrease home bias. However, the intensity of religious feelings might have either a positive or negative effect on home bias. It should be noted that the empirical analysis proposed here is only concerned with the correlation between religious attitudes and home bias and that at this time we do not attempt to identify causal effects ${ }^{10}$. However, the analysis presented

\footnotetext{
${ }^{9}$ A number of studies (e.g. Chuah et al., 2009; Guiso et al., 2009) use the World Value Survey as a direct or indirect benchmark.

${ }^{10}$ The identification of causal effects would require the use of longitudinal (panel) data.
} 
here is perhaps the first empirical exploration of the hypothesis that religious attitudes might influence home bias.

We employ a series of standard probit models to analyse the correlation between four different dimensions of home bias (labour market choices; consumption of home-produced goods; choices over health care services provided by national versus foreign doctors and choices concerning consumption of cultural media) and religious attitudes. Religious attitudes are defined in terms of the extent of religious openness/tolerance; the importance of religion in an individual's life; and religious affiliation (Buddhism, Christianity, Hinduism, Hebraism, Islamism, using the category no religion as a baseline). We also include a series of variables about the intensity of religious beliefs (if an individual defines himself as a believer attending services; a believer not attending services; a believer with no specific religious affiliation; a syncretist; an agnostic and use atheist as base category). We control for demographic characteristics (age and gender) and a series of geographical variables (whether the individuals is a foreign student and the macro geographical area of the sample of origin: North, Central, Southern and Eastern Europe; North America; South America; and Asia). Finally, we also include in our regressions a set of country-specific macroecononomic variables imputed using publicly available data from the World Bank and the International Monetary Fund (IMF) ${ }^{11}$. For each country in our survey, these variables contain GDP, the size of trade in the economy as a percentage of GDP, unemployment rates, female labour participation rates and an index of research power ${ }^{12}$. We impute these variables because we believe that individuals' home bias may be smaller the richer is a country, the more open is a country to trade, the higher its research power. Also, individuals' home bias in labour market choices may be negatively related to unemployment and the extent of female labour participation. A full description of the variables used in this analysis and their summary statistics are reported in Appendix C.

\section{[INSERT TABLE 4 HERE]}

Table 4 reports the marginal effects of the probit models ${ }^{13}$. Models 1 and 2 analyse the effect of religious attitudes on labour market choices. Individuals are asked whether they would accept a temporary job abroad with the same working conditions and salary (Model 1) and whether they would accept a temporary job abroad with the same working conditions but a higher salary (Model 2). Models 3 and 4 present choices between home-produced and foreign goods (car and food, respectively) while Models 6, 7, 8 reveal preferences over foreign media, cultures and novels. Finally, Model 5 identifies individuals' preferences towards the use of health care (national versus foreign medical doctors). The dependent variables of these models are all dummy variables that proxy home bias, taking value 1 when an individual is not willing to accept a job abroad, prefers home

\footnotetext{
${ }^{11}$ All these variables refer to the year 2008 (the first year the survey was issued) and are available at the World Bank website (http://data.worldbank.org/) and the IMF website: (http://www.imf.org/external/data.htm).

${ }^{12}$ The index used is R\&D expenditure as a percentage of GDP of the country.

${ }^{13}$ Complete tables featuring all explanatory variables are available upon request.
} 
produced cars and food, has been attended by native medical doctors and has never been interested in the fruition of foreign media. In the specifications presented in this table, we concentrate on the effects of religious openness and the importance of religion in an individual's life on home bias. The set of variables about religious openness (Service, Holy Text and Believer) are dummy variables coded as increasing in closeness. Accordingly, a positive effect of these variables would imply that closed views on religion are associated with home bias. The group of variables on the relevance of religion (Abortion, Support, Welfare, Politics, Trade Freedom, State, School and Private) are dummy variables coded as increasing in the importance of religion. In this case, a positive effect of these variables would entail that the higher is the importance of religion the greater is home bias.

In four out of eight specifications, the variable Service displays positive and statistically significant marginal effects. Accordingly, having never attended a service of another religion is associated with home bias in choices concerning the labour market (Models 1 and 2) and consumption of cultural media (Models 6 and 7). Also, refusing to read a holy text from a different religion (Holy text) appears to display positive and statistically significant marginal effects in the models concerning the fruition of cultural media (6 and 7$)$. The third dummy identifying religious closedness (Believer, individuals that do not think positively nor respect individuals who define themselves as strong believers) seems to show a weaker effect on our home-bias revealing choices. Overall, this appears to provide some evidence that closed views on religion are positively associated with home bias. The effects of the importance of religion appear to be more mixed. Although this is somewhat consistent with our prior, it makes difficult to draw firm conclusions. For example, the importance of religion appears to be negatively associated with home bias for choices related to home branded/produced cars (Welfare in Model 3) whereas it seems to be positive correlated with home bias for choices concerning food (Welfare in Model 4). This might also imply that the importance of religion on an individual' life may lead individuals to have different preferences depending on the various domains of home bias.

The effects of religious affiliation on home bias also appear to present some mixed results. For example, Christians appear to present some tendencies for home bias only in specific domains. According to our models, they seem to prefer home doctors and to be less interested in the use of foreign media (Models 5 and 7). However, Christians also seem to be interested in foreign cultures in general (Model 7). Individuals defining themselves as Hindu appear to display the most consistent tendency towards home bias, although this is true for a limited number of models/home bias domains (labour market choices and food; Models 1, 2 and 4). Further, Buddhist and Muslim appear to display a generally negative correlation with home bias (food and cultural media; Models 4 and 7). It is worth noting that these results appear to differ slightly from the effects of religious denominations on trade identified previously in the literature. These differences, however, may be partly explained by the fact that we consider multiple domains of home bias rather than aggregate measures of trade; moreover, 
we account for a wider set of religious attitudes. Finally, a lower religious intensity appears to be negatively correlated with home bias (see models 1, 2, 6 and 8).

\section{Concluding Remarks}

This paper provides a first investigation of the relationship between religion and home bias using both a theoretical framework and evidence from a survey that we designed and collected. Whereas the previous literature has focused primarily on the effects of religious denominations on bilateral trade flows, we analyze the influence of a series of religious attitudes on different domains of home bias. In particular, this paper attempts to establish whether and how attitudes towards religion, through altruism and trust, influence individual preferences for homeproduced versus foreign goods and services..

We employ a simple two-country theoretical framework and show that religious driven international altruism should increase trade openness and reduce home bias. We explore this empirically using new data from a pilot survey handed out to students of 16 universities throughout 15 different countries. According to our empirical analysis, religious openness and home bias appear to be negatively associated within most home bias domains. This finding seems to support the hypothesis that religious-rooted altruism may have a pro-trade effect and, hence, decrease home bias. We also find that the importance of religion in an individual's life may drive individuals to have different preferences towards home bias depending on the different domains of home bias considered. Moreover, religious affiliations appear to have less clear-cut effects on individuals' economic choices than previously identified in the literature on religion and trade. Overall, our results appear to corroborate the hypothesis that religion can play an important role in defining home bias. Our empirical findings also highlight the importance of accounting for different religious attitudes beyond simple religious affiliation when analysing the relationship between religion and home bias. As individuals appear to display different preferences towards home bias, they also suggest the need of accounting for different domains of home bias.

More definite conclusions can be only achieved by collecting more data on these issues. In particular, our study could be extended and improved by using representative samples of the population of the different countries analysed. Also, longitudinal data could allow studying the dynamics of the religious openness-home bias relationship. 


\section{References}

[1] Adler M., and B. Dumas (1983), "International portfolio choice and corporation finance: a synthesis", Journal of Finance, 38(3), 925-984.

[2] Ahearne A.G., Griever W.L. and Warnock F.E. (2004), "Information costs and home bias: an analysis of US holdings of foreign equities", Journal of International Economics, 62(2), 313-336.

[3] Bahr H.M., and T.K. Martin (1983), " And thy neighbour as thyself": selfesteem and faith in people as correlates of religiosity and family solidarity among Middletown high school students", Journal for the Scientific Study of Religion, 22(2), 132-144.

[4] Barro R.J., and R. M. McCleary (2003), "Religion and Economic Growth," NBER Working Paper No. 9682.

[5] Barro R.J., and R. M. McCleary (2005), "Which Countries Have State Religions?" Quarterly Journal of Economics, 120, 1331-1370.

[6] Benjamin D. J., Choi, J.J.,and G. W. Fisher (2010) "Religious Identity and Economic Behavior," NBER Working Paper No. 15925.

[7] Becker S., and L. Woessman (2009), "Was Weber wrong? A human capital theory of Protestant economic history", Quarterly Journal of Economics, 124(2), 531-596.

[8] Blum, U. and L. Dudley (2001), "Religion and Economic Growth: Was Weber Right?" Journal of Evolutionary Economics, 11, 207-230.

[9] Bradford S.C., and R. Lawrence (2002), "Has globalization gone far enough?", Institute for International Economics, Washington D.C.

[10] Butler J., Giuliano P. and L. Guiso (2009), "The right amount of trust," NBER Working Paper No.15344.

[11] Cavalcanti T. V., Parente S.L. and R. Zhao (2007), "Religion in Macroeconomics: A Quantitative Analysis of Weber's Thesis," Economic Theory, 32, 105-123.

[12] Chuah S.H., Hoffmann R., Jones M. and G. Williams (2009), "An economic anatomy of culture: attitudes and behaviour in inter- and intra-national ultimatum game experiments", Journal of Economic Psychology, 30, 732744 .

[13] Dixit A. (2009), "Governance Institutions and Economic Activity", American Economic Review, 99(1), 5-24.

[14] Economist YouGovPolimetrix (2008), "Anglo-Saxon attitudes: a survey of British and American views of the world". Accessible online at: http://www.economist.com/node/10927596. 
[15] Ekelund R. B. Jr., Hebert R.F. and R.D. Tollison (2002), "An Economic Analysis of the Protestant Reformation," Journal of Political Economy, 110, 646-671.

[16] Finke R., and R. Stark (1988), "Religious economies and sacred canopies: religious mobilization in American cities, 1906", American Sociological Review, 53(1), 41-49

[17] Finke R., and R. Stark (1989), "How the upstart sects won America: 17761850", Journal for the Scientific Study of Religion, 28(1), 27-44.

[18] Forsythe R., Horowitz J.L., Savin N.E. and M. Sefton (1994), "Fairness in simple bargaining experiments", Games and Economic Behavior, 6(3), 347-369.

[19] Frankel J.F., Stein E. and S.J. Wei (1995), "Regional trading arrangemnts: natural or supernatural?", American Economic Review, 86(2), 52-56.

[20] French K.R., and J.M. Poterba (1991), "Investor diversification and international equity markets", American Economic Review, 81(2), 222-226.

[21] Glaeser E. L., La Porta, R., Lopez-de-Silanes, F., and A. Shleifer (2004), "Do institutions cause growth?" Journal of Economic Growth, 9, 271-303.

[22] Greif A. (1989), "Reputation and Coalitions in Medieval Trade: The Evidence on the Maghribi Traders," The Journal of Economic History, 49, 857-882.

[23] Greif A. (1992), "Institutions and International Trade: Lessons from the Commercial Revolution," American Economic Review, 82, 128-133.

[24] Greif A. (1993), "Contract Enforceability and Economic Institutions in Early Trade: The Maghribi Traders' Coalition," American Economic Review, 83, 525-548.

[25] Greif A. (1994), "Cultural Beliefs and the Organization of Society: A Historical and Theoretical Reflection on Collectivist and Individualist Societies," Journal of Political Economy, 102, 912-950.

[26] Gruber J., and D. M. Hungerman (2008), "The Church versus the Mall: What Happens When Religion Faces Increased Secular Competition?", Quarterly Journal of Economics, 123(2), 831-862.

[27] Guiso L., Sapienza P. and L. Zingales (2003), "People's opium? Religion and economic attitudes", Journal of Monetary Economics, 50, 225-282.

[28] Guiso L., Sapienza P. and L. Zingales (2006), "Does Culture Affect Economic Outcomes?", Journal of Economic Perspectives, 20, 23-48.

[29] Guiso L., Sapienza P. and L. Zingales (2009), "Cultural Biases in Economic Exchange?", The Quarterly Journal of Economics 124, 1095-1131. 
[30] Helble M. (2007), "Is God good for trade?", Kyklos, 60(3), 385-413.

[31] Heliwell J.F. (1998), "How much do national borders matter?", Brookings Institution, Washington D.C.

[32] Henrich J., Ensminger J., McElreath R., Barr A., Barrett C., Bolyanatz A., Cardenas J.C., Gurven M., Gwako E., Henrich N., Lesorogol C., Marlowe F., Tracer D. and J. Ziker (2010), "Markets, Religion, Community Size and the Evolution of Fairness and Punishment", Science, 327, 1480-1484.

[33] Hoff K. (2010), "Fairness in modern societies", Science, 327, 1467-1468.

[34] Hungerman D.M. (2011), "Do religious proscriptions matter? Evidence from a theory-based test", NBER Working Paper no. 17375.

[35] Iannaccone L. R. (1992), "Sacrifice and Stigma: Reducing Free-Riding in Cults, Communes, and Other Collectives", Journal of Political Economy, 100, 271-292.

[36] Iannaccone L. R. (1998), "Introduction to the Economics of Religion", Journal of Economic Literature, 36, 1465-1496.

[37] Knack S. and P. Keefer (1997), "Does social capital have an economic payoff? A cross-country investigation", Quarterly Journal of Economics, 112(4), 1251-1288.

[38] La Porta R., Lopez de Silanes F., Shleifer A. and R.W. Vishny (1997), "Legal determinants of external finance", Journal of Finance, 52(3), 11311150 .

[39] Laury S.K. and L.O. Taylor (2008), "Altruism spillovers: are behaviors in context-free experiments predictive of altruism towards a naturally occurring public good", Journal of Economic Behavior and Organization, 65(1), 9-29.

[40] Leeson P. T. (2005), "Endogenizing Fractionalization", Journal of Institutional Economics, 1, 75-98.

[41] Lewer J.J. and H. Van den Berg (2007a), "Religion and international trade", American Journal of Economics and Sociology, 66(4), 765-794.

[42] Lewer J.J. and H. Van den Berg (2007b), "Estimating the institutional and network effects of religious cultures on international trade", Kyklos, 60(2), 255-277.

[43] Lewis K.K. (1999), "Trying to explain home bias in equities and consumption", Journal of Economic Literature, 37, 571-608.

[44] Lindbeck A. and S. Nyberg (2006), "Raising Children to Work Hard: Altruism, Work Norms, and Social Insurance" Quarterly Journal of Economics, 121, 1473-1503. 
[45] McCallum J. (1995), "National borders matter: Canada-US regional trade patterns", American Economic Review, 85, 615-623.

[46] Montgomery J. (2003), "A formalization and test of the religious economies model", American Sociological Review, 68(5), 782-809.

[47] Nordas H.K. (2010), "Trade in goods and services: two sides of the same coin?", Economic Modelling, 27(2), 496-506.

[48] Obstfeld M., and K. Rogoff, (2000), "The Six Major Puzzles in International Macroeconomics: Is There a Common Cause?" NBER working paper No. 7777 .

[49] Reggiani C. and G. Rossini (forthcoming), "Economic Home Bias and Cultural Individual Attitudes: A Study on European Students", Interdisciplinary Journal of Business Law and Economics.

[50] Schoenfeld E. (1978), "Image of man: the effect of religion on trust", Review of Religious Research, 20(1), 61-67.

[51] Sercu P., and R. Vanpee (2007), "Home bias in international equity portfolios: a review", Leuven School of Business working paper.

[52] Smith A. (1776), "An Inquiry into the Nature and Causes of the Wealth of Nations", Modern Library, New York, 1965.

[53] Stulz R.M. (1981), "On the effects of barriers on international investment", Journal of Finance, 36(4), 923-934.

[54] Stulz R.M. (2005), "The limits of financial globalization", Journal of Finance, 60(4), 1595-1638.

[55] Tabellini G. (2008), "The Scope of Cooperation: Values and Incentives" Quarterly Journal of Economics, 123, 905-50.

[56] Tesar L.L., and I.M. Werner (1995), "Home bias and high turnover", Journal of International Money and Finance, 14(4), 467-492.

[57] Voas D., Crockett A. and D.V.A. Olson (2002), "Religious pluralism and participation: why previous research is wrong", American Sociological Review, $\mathbf{6 7}(2), 212-230$.

[58] Weber M. (1930), "The Protestant Ethic and the Spirit of Capitalism", Free Press, New York, 1958.

[59] World Value Survey (2005). Details online at: http://www.worldvaluessurvey.org/index_surveys. 


\section{Acknowledgments}

This research owes a lot to a long list of colleagues who helped us around the World to hand out questionnaires to students and, in many occasions, to improve questions and research. We wish to thank Oded Galor at Brown University, United States; Huasheng Song at the School of Economics, Zhejiang University, Hangzhou, China; Tom Coupé and Yana Ponomarova at the Kiev School of Economics, Ukraine; Yossi Spiegel at the Recanati Graduate School of Business Administration, Tel Aviv, Israel; Marius Bruelhart at the University of Lausanne, Switzerland; Federico Trionfetti at the University of Marseille - Aix en Provence, France; Vicente Donato at the University of Bologna in Buenos Aires, Argentina; Remzi Sanver at Bilgi University in Istanbul, Turkey; Ken Green and Larry Roberts at the New York State University in Binghampton, United States; Mariusz Krawczyk at Ryukoku University in Kyoto, Japan; Hannu Nurmi at the University of Turku, Finland; Vikas Kumar at the National Law School in Bangalore, India; Vesa Kanniainen at the University of Helsinki; Iorgos Marios Chrysanthou at Universidad Carlos III, Madrid, Spain. We wish to thank Olena Ognezdilova, Caterina Degani, Francesca Tolomei, Monica Stagnaro, Satoko Takenoshita, Lehan Jin, Francesca Cevolani for the preciuos help received for the translation in foreign languages of the questionnaires; Vytas Bautrenas for the invaluable research assistantship. For comments, suggestions and encouragment we acknowledge the contributions of Tim Brown, Marco Casari, Manfred Holler, Romano Prodi, Remzi Sanver, Yossi Spiegel, Cecilia Vergari and the participants in the ASREC meeting held in Arlington (VA) April, 7-10 2011. We finally acknowledge the financial support by the university of Bologna within the 2009-2010-2011 RFO funds and by the DERS, University of York for the Super Pump Priming funding 2010. 


\section{Appendix A}

The questionnaire: English language version for the US

\section{PART I}

- $\quad$ Please specify your age

- $\quad$ Please specify your sex MALE FEMALE

- Would you be willing to accept a TEMPORARY (max. 3 years) job in a foreign country for the same salary and work conditions of your home country? YES NO NOT SURE

... and for a salary at least $20 \%$ higher? YES NO NOT SURE

- $\quad$ Between a US made car and a car made outside the US with similar features and same price, which one will you prefer?

US FOREIGN INDIFFERENT

- $\quad$ Do you prefer to buy locally produced rather than imported food? LOCAL IMPORTED INDIFFERENT

- If you needed a doctor and had the choice between one from the US and one from the rest of the world (ROW), which one would you prefer? US ROW INDIFFERENT

- Do you prefer to read novels by writers of your nationality? YES NO NOT SURE

- $\quad$ Do you watch foreign TV news / read foreign newspapers / use other foreign media?

\section{OFTEN RARELY NEVER}

- Do you consider yourself as being interested in foreign cultures? YES NO NOT SURE

- How many times did you travel to a foreign country during the last 2 years?

$[<5][5-10][>10]$

- How many foreign friends do you have? [NONE] [1-5] [6-10] [>10]

- Would you mind the US trading with a country where there is no religious freedom?...........

YES NO DO NOT KNOW.

- If a country raises trade barriers against US, what would you suggest?

WAIT RETALIATE IGNORE

- What is your nationally? US FOREIGN

\section{PART II}

- $\quad$ As to religion, do you consider yourself as:

- a believer regularly attending services of your confession

- a believer not attending services

- a believer with no religious affiliation

- a syncretist (believe in the fusion of many religions)

- an atheist 
- an agnostic (existence of God cannot be proved)

- other ............

- Did you ever attend services of a religion which is not yours,

- in your home country? ONCE MORE THAN ONCE NEVER

- during a journey abroad? ONCE MORE THAN ONCE NEVER

- Would you read holy texts of religions which are not yours? YES NEVER

- Should religion give you guidance to questions such as abortion? YES NO NOT SURE

- Should religion give you guidance to questions such as the welfare state? YES NO NOT SURE

- On the whole, how important do you think religion in general is for your private life?

VERY IMPORTANT NOT VERY IMPORTANT NOT IMPORTANT

AT ALL

- Do you respect or think positive of people who consider themselves as strong believers?

RESPECT THINK POSITIVE BOTH NEITHER NOT SURE

- Do you believe that there is a hell, where sinners who do not repent their sins go when they die?

YES I DO NO I DON'T NOT SURE

- Do you think one religion should be actively supported by the state? YES NO NOT SURE

- Do you think that most common religions should be actively supported by the state?

YES NO NOT SURE

- Do you think religion should have some influence on politics? YES NO NOT SURE

- Should your country trade freely with a state without religious freedom? YES NO NOT SURE

- Should there be a state religion in your country? YES NO NO OPINION

- Do you think that religious principles should be taught at school? YES NO NO OPINION

- If you wish, please name your religious affiliation. ............... 


\section{Appendix B}

Comparison with other surveys

Table B.1: comparison with the World Values Survey (2005)

\begin{tabular}{|c|c|c|c|c|}
\hline \multicolumn{2}{|c|}{ Importance of Religion } & \multirow[t]{2}{*}{ Country } & \multicolumn{2}{|c|}{ Guidance to Welfare } \\
\hline Our Study & WVS & & Our Study & WVS \\
\hline 15.9 & 21.0 & UK & 16.0 & - \\
\hline 21.6 & 34.4 & Italy & 10.8 & 50.5 \\
\hline 35.6 & 74.7 & Turkey & 23.8 & 57.2 \\
\hline 7.0 & - & Israel & 7.1 & - \\
\hline 33.6 & 18.3 & Ukraine & 23.1 & 63.5 \\
\hline 13.7 & 17.1 & Switzerland & 3.6 & 58.1 \\
\hline 22.3 & 13.0 & France & 3.7 & - \\
\hline 20.5 & 11.2 & Germany & 28.5 & 70.4 \\
\hline 18.4 & 14.9 & Spain & 14.3 & 75.6 \\
\hline 20.4 & 6.7 & China & 23.1 & - \\
\hline 10.5 & 17.6 & Finland & 7.9 & 61.5 \\
\hline 30.9 & 62.3 & India & 28.4 & 61.5 \\
\hline 5.1 & 6.5 & Japan & 4.0 & 92.4 \\
\hline 19.2 & 47.4 & USA & 14.3 & 56.1 \\
\hline
\end{tabular}

Table B.2: comparison with the Economist poll, belief in hell

\begin{tabular}{lllll}
\hline & \multicolumn{2}{c}{ Economist } & \multicolumn{2}{c}{ Our study } \\
\hline & US & UK & US & UK \\
\hline Yes & 54.0 & 16.0 & 30.0 & 15.0 \\
No & 27.0 & 57.0 & 43.0 & 44.0 \\
Not Sure & 19.0 & 27.0 & 23.0 & 38.0 \\
\hline
\end{tabular}




\section{Appendix C}

\section{List of variables used in the empirical analysis}

- Home bias proxies

Job Abroad: dummy identifying individuals with no willingness to accept a temporary job abroad for the same salary as at home.

Job Abroad 20: dummy identifying individuals with no willingness to accept a temporary job abroad for a salary $20 \%$ higher than at home.

Car: dummy identifying individuals with preference for the home made (brand) car.

Media: dummy identifying individuals that never watch foreign TV news / read foreign newspapers/ use other foreign media.

Doctor: dummy identifying individuals with preference for the home doctor.

Food: dummy identifying individuals with preference for locally produced food.

Culture: dummy identifying individuals with no interest for foreign cultures.

Novel: dummy identifying individuals with preference for novels written by writers of same nationality.

- Religious openness/closedness proxies

Service: dummy identifying individuals that never attended a service of another religion.

Holy Text: dummy identifying individuals with no willingness to read a holy text of a different religion.

Believer: dummy identifying individuals that neither think positive nor respect a person that describes himself as a strong believer.

- Importance of religion proxies

Abortion: dummy to signal an individual who thinks religion should give guidance on questions like abortion.

Welfare: dummy to signal an individual who thinks religion should give guidance on questions like welfare.

Private: dummy to signal an individual who thinks religion is very important for their private life.

State: dummy to signal an individual who thinks that one religion should be actively supported by the state.

Support: dummy to signal an individual who thinks the most common religions should be actively supported by the state. 
Politics: dummy to signal an individual who thinks religion should have some influence on politics.

School: dummy to signal an individual who thinks that religious principles should be taught in school.

Trade Freedom: dummy to signal an individual who thinks that his country should trade freely with a state without religious freedom.

- Religious affiliation

Christian: dummy identifying individuals describing themselves of Christian religion.

Hindu: dummy identifying individuals describing themselves of Hindu religion.

Jewish: dummy identifying individuals describing themselves of Jewish religion.

Buddhist: dummy identifying individuals describing themselves of Buddhist religion.

Muslim: dummy identifying individuals describing themselves of Muslim religion.

- Religious intensity

Atheist: dummy identifying individuals describing themselves as atheists.

Agnostic: dummy identifying individuals describing themselves as agnostic.

Syncretist: dummy identifying individuals describing themselves as syncretist.

No affiliation: dummy identifying individuals describing themselves as believers with no affiliation.

No attendance: dummy identifying individuals describing themselves as believers not attending services of their religion.

Attendant: dummy identifying individuals describing themselves as believers attending services of their religion.

- Demographic characteristics

Sex: dummy identifying a female individual when taking value 1 .

Age: declared age of the individual in years.

- Geographic characteristics

North Europe: dummy to identify the Finland and UK samples.

Centre Europe: dummy to identify the France, Germany and Switzerland samples.

South Europe: dummy to identify the Italy and Spain samples. 
East Europe: dummy to identify the Ukraine sample.

Middle East: dummy to identify the Israel and Turkey samples.

Asia: dummy to identify the China, Japan and India samples.

South America: dummy to identify the Argentina sample.

North America: dummy to identify USA sample.

Country: dummy identifying a home student when taking value 1 .

Small Size: dummy variable identifying a student coming from a country with a population of less than 15 millions.

Medium Size: dummy variable identifying a student coming from a country with a population between 15 and 50 millions.

Large Size: dummy variable identifying a student coming from a country with a population of more than 50 millions.

- Aggregate economic indicators

Trade: trade as a percentage of GDP, World Bank data, 2009.

GDPpc: GDP per capita, World Bank data, 2009.

Labour Female: female participation rate to the labour market, World Bank data, 2009.

Unemployment: unemployment rate, World Bank data, 2009.

$R \& D$ : expenditure in research and development as a percentage of GDP, World Bank data, 2009.

[INSERT TABLE C.1 HERE] 


\section{Table 2. Religious attitudes}

Religious openess

Attended services of other religion in your country

\begin{tabular}{lll} 
Once & More & Never \\
524 & 257 & 932 \\
$30 \%$ & $15 \%$ & $53 \%$ \\
\multicolumn{3}{l}{} \\
\multicolumn{3}{l}{ Read holy text of other religions } \\
Never & Yes & Not sure \\
455 & 979 & 265 \\
$26 \%$ & $56 \%$ & $15 \%$
\end{tabular}

Religious importance

Religion as guidance for abortion

$\begin{array}{lll}\text { Yes } & \text { No } & \text { Not Sure } \\ 313 & 1082 & 321 \\ 18 \% & 62 \% & 18 \%\end{array}$

One religion supported by state

Yes No Not Sure

$129 \quad 1397 \quad 205$

$7 \% \quad 80 \% \quad 12 \%$

Trade with country without religious freedom

$\begin{array}{lll}\text { Yes } & \text { No } & \text { Not Sure } \\ 776 & 394 & 549 \\ 44 \% & 22 \% & 31 \%\end{array}$

Shdould religious principles be taught at school

Yes No No opinion

$688 \quad 799 \quad 265$

$39 \% \quad 44 \% \quad 15 \%$

Religious intensity

Believer - "Do you consider yourself as a ..."

$\begin{array}{lll}\text { Believer attending services } \% & \text { Believer not attending services \% } & \text { Believer with no affiliation \% } \\ 237 & 452 & 255 \\ 14 \% & 26 \% & 15 \% \\ & & \\ \text { Syncretistic } & \text { Atheist } & \text { Agnostic } \\ 101 & 371 & 226 \\ 6 \% & 21 \% & 13 \%\end{array}$

\begin{tabular}{|c|c|c|c|c|}
\hline \multicolumn{5}{|c|}{...in a foreign country } \\
\hline Once & More & \multicolumn{3}{|l|}{ Never } \\
\hline 301 & 221 & \multicolumn{3}{|l|}{1092} \\
\hline $17 \%$ & $13 \%$ & \multicolumn{3}{|l|}{$62 \%$} \\
\hline \multicolumn{5}{|c|}{ Respect or think positive of strong believers } \\
\hline Both & Respect & Think pos & Neither & Not Sure \\
\hline 273 & 416 & 177 & 587 & 263 \\
\hline $16 \%$ & $24 \%$ & $10 \%$ & $33 \%$ & $15 \%$ \\
\hline
\end{tabular}

Religion as guidance to welfare state

Yes No Not Sure

$286 \quad 1097 \quad 333$

Should religion have influence on politics

Yes No Not Sure

$178 \quad 1429 \quad 125$

$10 \% \quad 82 \% \quad 7 \%$

Should common religions be supported by state

$\begin{array}{lll}\text { Yes } & \text { No } & \text { Not Sure } \\ 239 & 1138 & 295 \\ 16 \% & 65 \% & 17 \%\end{array}$

Importance of religion in private life

Very Not very Not at all

$356 \quad 746 \quad 609$

$20 \% \quad 43 \% \quad 35 \%$
$16 \% \quad 63 \% \quad 19 \%$ 
Table 3. Home Bias Indicators

Labour Market

Willing to take up a job abroad...

Yes No Not Sure

$820 \quad 502 \quad 410$

...for a $20 \%$ higher salary

$47 \% \quad 29 \% \quad 23 \%$

Yes No Not Sure

$1146 \quad 225 \quad 356$

$65 \% \quad 13 \% \quad 20 \%$

Consumption of goods and services

Would you buy a local brand car

Prefer local over imported food

Yes No Not Sure

Yes No Indifferent

$705 \quad 348 \quad 694$

$971 \quad 62 \quad 510$

$40 \% \quad 20 \% \quad 40 \%$

$55 \% \quad 4 \% \quad 29 \%$

Prefer local over non-local doctor

Yes No Indifferent

$983 \quad 121 \quad 637$

$56 \% \quad 7 \% \quad 36 \%$

Foreign culture and international socialization

Prefer writer of own nationality

Yes No Not Sure

$445692 \quad 603$

Interest in foreign cultures

$25 \% \quad 39 \% \quad 34 \%$

Yes No Not Sure

$1453 \quad 116 \quad 174$

$83 \% \quad 7 \% \quad 10 \%$

Follow foreign media

How many friends from abroad

Yes No Not Sure

None $\quad 1$ to $5 \quad 6$ to $10 \quad 10+$

$834 \quad 154 \quad 760$

$255 \quad 736 \quad 242 \quad 505$

$48 \% \quad 9 \% \quad 43 \%$

$15 \% \quad 42 \% \quad 14 \%$

$29 \%$

No. of travels abroad in last 2 years

5 or less 5 to $10 \quad 10+$

$1337 \quad 310 \quad 85$

$76 \% \quad 18 \% \quad 5 \%$ 


\begin{tabular}{|c|c|c|c|c|c|c|c|c|}
\hline & $\begin{array}{c}\text { (1) } \\
\text { Job Abroad } \\
\end{array}$ & $\begin{array}{c}(2) \\
\text { Job Abroad } 20 \\
\end{array}$ & $\begin{array}{l}(3) \\
\text { Car } \\
\end{array}$ & $\begin{array}{c}(4) \\
\text { Food } \\
\end{array}$ & $\begin{array}{c}(5) \\
\text { Doctor }\end{array}$ & $\begin{array}{c}(6) \\
\text { Media } \\
\end{array}$ & $\begin{array}{c}(7) \\
\text { Culture }\end{array}$ & $\begin{array}{c}(8) \\
\text { Novel }\end{array}$ \\
\hline \multicolumn{9}{|c|}{ Religious openness } \\
\hline Service & $\begin{array}{c}0.0620^{* *} \\
(0.0276)\end{array}$ & $\begin{array}{c}0.0315^{* *} \\
(0.0160)\end{array}$ & $\begin{array}{l}-0.0393 \\
(0.0313)\end{array}$ & $\begin{array}{l}-0.0175 \\
(0.0318)\end{array}$ & $\begin{array}{c}-0.000206 \\
(0.0307)\end{array}$ & $\begin{array}{c}0.0283 * * * \\
(0.00926)\end{array}$ & $\begin{array}{c}0.0260 * * * \\
(0.00887)\end{array}$ & $\begin{array}{c}0.0310 \\
(0.0252)\end{array}$ \\
\hline Holy Text & $\begin{array}{c}0.0496 \\
(0.0344)\end{array}$ & $\begin{array}{c}0.0273 \\
(0.0225)\end{array}$ & $\begin{array}{l}-0.0225 \\
(0.0361)\end{array}$ & $\begin{array}{c}-0.00155 \\
(0.0351)\end{array}$ & $\begin{array}{l}-0.0472 \\
(0.0364)\end{array}$ & $\begin{array}{c}0.0671 * * * \\
(0.0203)\end{array}$ & $\begin{array}{c}0.0671 * * * \\
(0.0215)\end{array}$ & $\begin{array}{c}0.0495 \\
(0.0314)\end{array}$ \\
\hline Believer & $\begin{array}{c}0.0280 \\
(0.0319)\end{array}$ & $\begin{array}{l}-0.00513 \\
(0.0184)\end{array}$ & $\begin{array}{l}-0.0579^{*} \\
(0.0338)\end{array}$ & $\begin{array}{l}-0.0305 \\
(0.0369)\end{array}$ & $\begin{array}{l}-0.0169 \\
(0.0343)\end{array}$ & $\begin{array}{c}-0.0128 \\
(0.00964)\end{array}$ & $\begin{array}{l}-0.00103 \\
(0.0103)\end{array}$ & $\begin{array}{l}-0.0197 \\
(0.0280)\end{array}$ \\
\hline \multicolumn{9}{|l|}{ Importance } \\
\hline Abortion & $\begin{array}{l}-0.0227 \\
(0.0398)\end{array}$ & $\begin{array}{c}0.0144 \\
(0.0261)\end{array}$ & $\begin{array}{l}-0.0103 \\
(0.0445)\end{array}$ & $\begin{array}{l}-0.00959 \\
(0.0478)\end{array}$ & $\begin{array}{l}-0.0483 \\
(0.0442)\end{array}$ & $\begin{array}{c}0.0124 \\
(0.0190)\end{array}$ & $\begin{array}{c}0.0177 \\
(0.0183)\end{array}$ & $\begin{array}{l}0.00514 \\
(0.0371)\end{array}$ \\
\hline Welfare & $\begin{array}{l}-0.0593 \\
(0.0365)\end{array}$ & $\begin{array}{l}-0.00384 \\
(0.0226)\end{array}$ & $\begin{array}{l}-0.100 * * \\
(0.0408)\end{array}$ & $\begin{array}{l}0.141 * * * \\
(0.0405)\end{array}$ & $\begin{array}{l}-0.00711 \\
(0.0430)\end{array}$ & $\begin{array}{l}-0.0143 \\
(0.0126)\end{array}$ & $\begin{array}{l}0.00379 \\
(0.0148)\end{array}$ & $\begin{array}{c}0.0404 \\
(0.0367)\end{array}$ \\
\hline Support & $\begin{array}{l}-0.0279 \\
(0.0342)\end{array}$ & $\begin{array}{l}-0.0293 \\
(0.0188)\end{array}$ & $\begin{array}{l}-0.0521 \\
(0.0381)\end{array}$ & $\begin{array}{l}-0.00590 \\
(0.0391)\end{array}$ & $\begin{array}{l}-0.0325 \\
(0.0388)\end{array}$ & $\begin{array}{l}-0.00769 \\
(0.0120)\end{array}$ & $\begin{array}{c}0.0114 \\
(0.0144)\end{array}$ & $\begin{array}{l}-0.0171 \\
(0.0304)\end{array}$ \\
\hline Politics & $\begin{array}{c}0.0973 * * \\
(0.0492)\end{array}$ & $\begin{array}{c}0.0102 \\
(0.0286)\end{array}$ & $\begin{array}{c}0.0415 \\
(0.0509)\end{array}$ & $\begin{array}{l}-0.0157 \\
(0.0517)\end{array}$ & $\begin{array}{c}0.0105 \\
(0.0492)\end{array}$ & $\begin{array}{c}-0.00780 \\
(0.0152)\end{array}$ & $\begin{array}{c}0.000371 \\
(0.0151)\end{array}$ & $\begin{array}{c}0.0229 \\
(0.0406)\end{array}$ \\
\hline Trade freedom & $\begin{array}{c}0.0403 \\
(0.0264)\end{array}$ & $\begin{array}{l}0.00573 \\
(0.0163)\end{array}$ & $\begin{array}{c}0.0315 \\
(0.0286)\end{array}$ & $\begin{array}{c}-0.0803 * * * \\
(0.0292)\end{array}$ & $\begin{array}{c}0.000466 \\
(0.0285)\end{array}$ & $\begin{array}{c}0.00963 \\
(0.00942)\end{array}$ & $\begin{array}{c}-0.00492 \\
(0.00924)\end{array}$ & $\begin{array}{c}0.0297 \\
(0.0241)\end{array}$ \\
\hline State & $\begin{array}{c}0.0181 \\
(0.0520)\end{array}$ & $\begin{array}{l}-0.0291 \\
(0.0267)\end{array}$ & $\begin{array}{c}0.0744 \\
(0.0590)\end{array}$ & $\begin{array}{c}0.0475 \\
(0.0570)\end{array}$ & $\begin{array}{c}0.0764 \\
(0.0552)\end{array}$ & $\begin{array}{c}0.0190 \\
(0.0275)\end{array}$ & $\begin{array}{l}-0.00572 \\
(0.0167)\end{array}$ & $\begin{array}{c}0.0336 \\
(0.0495)\end{array}$ \\
\hline School & $\begin{array}{l}0.0495^{*} \\
(0.0295)\end{array}$ & $\begin{array}{l}0.0370 * \\
(0.0190)\end{array}$ & $\begin{array}{l}0.00681 \\
(0.0314)\end{array}$ & $\begin{array}{c}0.0363 \\
(0.0329)\end{array}$ & $\begin{array}{l}-0.0181 \\
(0.0312)\end{array}$ & $\begin{array}{c}0.0123 \\
(0.0111)\end{array}$ & $\begin{array}{l}-0.0164 \\
(0.0101)\end{array}$ & $\begin{array}{c}0.0288 \\
(0.0268)\end{array}$ \\
\hline Private & $\begin{array}{l}-0.0199 \\
(0.0384)\end{array}$ & $\begin{array}{l}-0.0144 \\
(0.0216)\end{array}$ & $\begin{array}{c}0.0480 \\
(0.0442)\end{array}$ & $\begin{array}{l}-0.0150 \\
(0.0462)\end{array}$ & $\begin{array}{c}0.0773^{*} \\
(0.0418)\end{array}$ & $\begin{array}{l}-0.0180 \\
(0.0126)\end{array}$ & $\begin{array}{l}-0.0109 \\
(0.0124)\end{array}$ & $\begin{array}{c}0.0552 \\
(0.0386)\end{array}$ \\
\hline Affiliation & & & & & & & & \\
\hline Christian & $\begin{array}{l}0.00839 \\
(0.0388)\end{array}$ & $\begin{array}{l}-0.0154 \\
(0.0236)\end{array}$ & $\begin{array}{c}-0.00604 \\
(0.0398)\end{array}$ & $\begin{array}{c}-0.0552 \\
(0.0433)\end{array}$ & $\begin{array}{c}0.1000 * * * \\
(0.0385)\end{array}$ & $\begin{array}{c}0.0426 * * \\
(0.0189)\end{array}$ & $\begin{array}{c}-0.0246^{* *} \\
(0.0121)\end{array}$ & $\begin{array}{c}0.0299 \\
(0.0358)\end{array}$ \\
\hline Hindu & $\begin{array}{c}0.163^{*} \\
(0.0856)\end{array}$ & $\begin{array}{l}0.165 * * \\
(0.0800)\end{array}$ & $\begin{array}{l}-0.0394 \\
(0.0818)\end{array}$ & $\begin{array}{c}0.172 * * * \\
(0.0621)\end{array}$ & $\begin{array}{c}0.0289 \\
(0.0798)\end{array}$ & $\begin{array}{c}0.0619 \\
(0.0981)\end{array}$ & $\begin{array}{c}-0.00441 \\
(0.0210)\end{array}$ & $\begin{array}{c}0.0115 \\
(0.0663)\end{array}$ \\
\hline Jewish & $\begin{array}{c}0.0863 \\
(0.0787)\end{array}$ & $\begin{array}{l}-0.0297 \\
(0.0396)\end{array}$ & $\begin{array}{c}0.125 \\
(0.0887)\end{array}$ & $\begin{array}{l}-0.0565 \\
(0.0797)\end{array}$ & $\begin{array}{l}0.00629 \\
(0.0823)\end{array}$ & $\begin{array}{l}0.00812 \\
(0.0296)\end{array}$ & $\begin{array}{l}-0.00443 \\
(0.0204)\end{array}$ & $\begin{array}{l}-0.0263 \\
(0.0612)\end{array}$ \\
\hline Buddhist & $\begin{array}{c}-0.0458 \\
(0.0784)\end{array}$ & $\begin{array}{c}-0.0154 \\
(0.0409)\end{array}$ & $\begin{array}{c}0.0308 \\
(0.0908)\end{array}$ & $\begin{array}{c}-0.0546 \\
(0.0977)\end{array}$ & $\begin{array}{l}-0.0402 \\
(0.0923)\end{array}$ & $\begin{array}{l}0.00535 \\
(0.0257)\end{array}$ & $\begin{array}{c}-0.0288 * * * \\
(0.00869)\end{array}$ & $\begin{array}{c}0.124 \\
(0.0891)\end{array}$ \\
\hline Muslim & $\begin{array}{c}0.139 \\
(0.0915)\end{array}$ & $\begin{array}{c}0.0816 \\
(0.0787)\end{array}$ & $\begin{array}{l}-0.0598 \\
(0.0827)\end{array}$ & $\begin{array}{l}-0.166^{*} \\
(0.0969)\end{array}$ & $\begin{array}{l}0.00659 \\
(0.0837)\end{array}$ & $\begin{array}{c}0.0494 \\
(0.0795)\end{array}$ & $\begin{array}{c}-0.0321 * * * \\
(0.00787)\end{array}$ & $\begin{array}{c}0.0988 \\
(0.0836)\end{array}$ \\
\hline
\end{tabular}




\begin{tabular}{|c|c|c|c|c|c|c|c|c|}
\hline \multicolumn{9}{|l|}{ Intensity } \\
\hline Agnostic & 0.0589 & 0.00243 & 0.0716 & 0.0105 & -0.0662 & 0.00508 & 0.0101 & -0.0362 \\
\hline & $(0.0472)$ & $(0.0281)$ & $(0.0483)$ & $(0.0466)$ & $(0.0475)$ & $(0.0152)$ & $(0.0180)$ & $(0.0375)$ \\
\hline \multirow[t]{2}{*}{ Syncretist } & $-0.120 * * *$ & $-0.0594 * * *$ & 0.0152 & 0.0448 & -0.0922 & -0.00451 & -0.00501 & -0.0202 \\
\hline & $(0.0458)$ & $(0.0206)$ & $(0.0650)$ & $(0.0606)$ & $(0.0632)$ & $(0.0177)$ & $(0.0192)$ & $(0.0482)$ \\
\hline No Affiliation & $(0.0414)$ & $(0.0227)$ & $(0.0468)$ & $(0.0482)$ & $(0.0466)$ & $(0.0106)$ & $(0.0194)$ & $(0.0354)$ \\
\hline \multirow[t]{2}{*}{ No Attendance } & 0.0237 & 0.0115 & 0.0264 & $0.0788^{*}$ & 0.0195 & -0.0118 & 0.0200 & $-0.0732 * *$ \\
\hline & $(0.0444)$ & $(0.0279)$ & $(0.0473)$ & $(0.0464)$ & $(0.0469)$ & $(0.0129)$ & $(0.0186)$ & $(0.0362)$ \\
\hline Attendant & $0.133 * *$ & 0.0406 & 0.0612 & 0.0112 & 0.0144 & -0.0172 & 0.0585 & -0.0431 \\
\hline Observations & 1,515 & 1,517 & 1,527 & 1,438 & 1,523 & 1,357 & 1,452 & 1,520 \\
\hline Log Likelihood & -790.3 & -505.5 & -910.3 & -309.0 & -969.9 & -801.9 & -291.1 & -692.5 \\
\hline
\end{tabular}

Standard errors in parentheses $* * * \mathrm{p}<0.01, * * \mathrm{p}<0.05, * \mathrm{p}<0.1$

Table 4. The effects of religious attitudes on home bias 
Table C.1 Summary statistics of variables used in the empirical analysis

\begin{tabular}{|c|c|c|c|c|c|}
\hline & Obs & Mean & SD & Min & Max \\
\hline Age & 1820 & 22.763 & 4.945 & 17 & 64 \\
\hline Sex & 1829 & 0.465 & 0.499 & 0 & 1 \\
\hline Country & 1697 & 0.854 & 0.353 & 0 & 1 \\
\hline Size & 1698 & 2.389 & 0.800 & 1 & 3 \\
\hline GDPpc & 1845 & 27014.680 & 13799.144 & 2868 & 47155 \\
\hline Trade & 1845 & 63.188 & 21.073 & 29 & 101 \\
\hline Unemployment & 1845 & 7002.844 & 2274.329 & 3500 & 11325 \\
\hline Female Labour & 1845 & 50.29106 & 10.7632 & 25 & 68 \\
\hline R\&D & 1845 & 2.031 & 1.137 & 1 & 5 \\
\hline Job Abroad & 1817 & 0.303 & 0.460 & 0 & 1 \\
\hline Job Abroad 20 & 1813 & 0.140 & 0.347 & 0 & 1 \\
\hline Car & 1832 & 0.402 & 0.490 & 0 & 1 \\
\hline Food & 1627 & 0.628 & 0.483 & 0 & 1 \\
\hline Doctor & 1825 & 0.570 & 0.495 & 0 & 1 \\
\hline Novel & 1825 & 0.252 & 0.434 & 0 & 1 \\
\hline Media & 1845 & 0.085 & 0.278 & 0 & 1 \\
\hline Culture & 1827 & 0.063 & 0.244 & 0 & 1 \\
\hline Travel & 1812 & 0.774 & 0.419 & 0 & 1 \\
\hline Friends & 1823 & 0.144 & 0.351 & 0 & 1 \\
\hline Service & 1845 & 0.721 & 0.448 & 0 & 1 \\
\hline Holy Text & 1782 & 0.264 & 0.441 & 0 & 1 \\
\hline Believer & 1802 & 0.244 & 0.430 & 0 & 1 \\
\hline Abortion & 1799 & 0.182 & 0.386 & 0 & 1 \\
\hline Welfare & 1798 & 0.175 & 0.380 & 0 & 1 \\
\hline Support & 1802 & 0.169 & 0.375 & 0 & 1 \\
\hline Politics & 1814 & 0.103 & 0.303 & 0 & 1 \\
\hline State & 1813 & 0.076 & 0.264 & 0 & 1 \\
\hline School & 1814 & 0.388 & 0.487 & 0 & 1 \\
\hline Private & 1795 & 0.214 & 0.410 & 0 & 1 \\
\hline Trade Freedom & 1801 & 0.459 & 0.498 & 0 & 1 \\
\hline Hindu & 1845 & 0.060 & 0.238 & 0 & 1 \\
\hline Buddhist & 1845 & 0.025 & 0.158 & 0 & 1 \\
\hline Orthodox & 1845 & 0.029 & 0.169 & 0 & 1 \\
\hline Agnostic & 1845 & 0.014 & 0.116 & 0 & 1 \\
\hline Muslim & 1845 & 0.049 & 0.215 & 0 & 1 \\
\hline Atheist & 1845 & 0.027 & 0.162 & 0 & 1 \\
\hline Jewish & 1845 & 0.051 & 0.220 & 0 & 1 \\
\hline Christian & 1845 & 0.328 & 0.470 & 0 & 1 \\
\hline No Religion & 1845 & 0.092 & 0.289 & 0 & 1 \\
\hline North America & 1845 & 0.073 & 0.260 & 0 & 1 \\
\hline South America & 1845 & 0.047 & 0.211 & 0 & 1 \\
\hline North Europe & 1845 & 0.116 & 0.320 & 0 & 1 \\
\hline South Europe & 1845 & 0.142 & 0.349 & 0 & 1 \\
\hline Centre Europe & 1845 & 0.240 & 0.427 & 0 & 1 \\
\hline East Europe & 1845 & 0.052 & 0.222 & 0 & 1 \\
\hline Mid East & 1845 & 0.117 & 0.321 & 0 & 1 \\
\hline
\end{tabular}




\begin{tabular}{|c|c|c|c|c|c|}
\hline Asia & 1845 & 0.215 & 0.411 & 0 & 1 \\
\hline Attendant & 1784 & 0.141 & 0.348 & 0 & 1 \\
\hline No Attendance & 1784 & 0.276 & 0.447 & 0 & 1 \\
\hline No Affiliation & 1784 & 0.147 & 0.355 & 0 & 1 \\
\hline Syncretist & 1784 & 0.061 & 0.240 & 0 & 1 \\
\hline Atheist & 1784 & 0.212 & 0.409 & 0 & 1 \\
\hline Agnostic & 1784 & 0.136 & 0.343 & 0 & 1 \\
\hline Small Size & 1845 & 0.185 & 0.388 & 0 & 1 \\
\hline Medium Size & 1845 & 0.193 & 0.395 & 0 & 1 \\
\hline Large Size & 1845 & 0.543 & 0.498 & 0 & 1 \\
\hline$N$ & 1845 & & & & \\
\hline
\end{tabular}




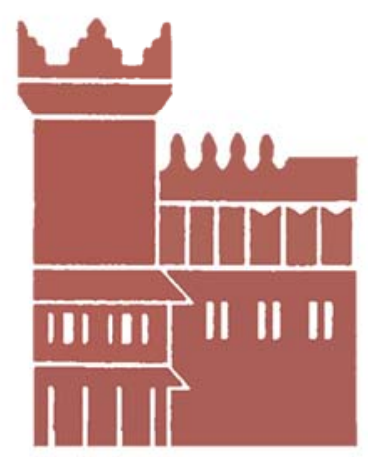

Alma Mater Studiorum - Università di Bologna DEPARTMENT OF ECONOMICS

Strada Maggiore 45

40125 Bologna - Italy

Tel. +39051 2092604

Fax +390512092664

http://www.dse.unibo.it 